\title{
Locavorism through Control Society Logic: An Analysis of the Possibilities of Food Activism and/or Brand Modeling
}

\author{
Margarete Ribeiro Tavares, Fred Tavares, Bárbara Lúcia Guimarães Alves, \\ Jefferson Fernando Gonçalves Guedes da Costa, Marlen Maria Cabral Ramalho
}

Psychosociology of Communities and Social Ecology (EICOS-IP/UFRJ), Rio de Janeiro, Brazil

Email:margatavares@yahoo.com.br

How to cite this paper: Tavares, M. R., Tavares, F., Alves, B. L. G., da Costa, J. F. G. G., \& Ramalho, M. M. C. (2019). Locavorism through Control Society Logic: An Analysis of the Possibilities of Food Activism and/or Brand Modeling. Advances in Applied Sociology, 9, 538-550.

https://doi.org/10.4236/aasoci.2019.911039

Received: October 11, 2019

Accepted: November 26, 2019

Published: November 29, 2019

Copyright $\odot 2019$ by author(s) and Scientific Research Publishing Inc. This work is licensed under the Creative Commons Attribution International License (CC BY 4.0).

http://creativecommons.org/licenses/by/4.0/ Open Access

\begin{abstract}
The purpose of this paper is to analyze the potential of Locavorism as a significant affluence, resistance and activism in the context of the Control Society, based on the discussions of Gilles Deleuze, Felix Guattari and others who dialogue with them. Locavorism is a social food movement that emerged around 2010 and is manifested by the consumption of locally grown food. From the perspective of green consumption, this practice develops due to the benefits of both the reduction of environmental impacts from large displacements, and the ecosystem effects of strengthening local cultural identities. Thus, this paper proposes to develop an examination of the interconnection between the concepts of capitalist culture, subjectivity, resistance and their theoretical articulation with the Locavorism movement as a strategy of subjectivity production and "line of escape". Therefore, the methodology adopted in this study is the bibliographic exploratory research through Content Analysis, identifying the principles, the operability and the analysis of its applicability in the organization and diffusion in the preponderant social networks of specific territories. As a result of the research, some clues about its potentialities and consistency will be pointed out as a possible alternative proposal to contemporary consumption models.
\end{abstract}

\section{Keywords}

Locavorism, Control Society, Food Activism, Brand Modeling

\section{Introduction}

The conception of the Consumption Society (Bauman, 2001) from the perspective of the Control Society (Deleuze, 1992) advances under the identity reality of 
the human being in order to develop parameters of demands with the ability to transform "being" into "having/to look". Prado (2012) refers this type of behavioral mutability to a kind of mobile subjectivity, where the individual is constantly born and reborn with new demands and visions about his reality. The author (op.cit.) Mentions that in the Control Society everyone controls everyone without a predefined logic, that is, the individual controls and is controlled from a consumption perspective in which social identity becomes a password to obtain the desired belonging. Contemporary consumption proves to be being disciplined by aspects that refer to social and environmental responsibility. As a result, brands that demonstrate these attributes tend to exhibit politically correct characteristics that attract people who agree with these peculiarities for consumption.

According to Tavares \& Ferreira (2012: p. 27), “[...] until the mid-1980s and 1990s, talking about responsible consumption was understood as something unimportant. Ecologically and socially correct products and services were very difficult to find". However, with the resource boom that allowed for greater access to the media, consumers were aiming for value goals beyond the price of the product or service or status. At this moment, the ethical, social and ecological aspect of products/services has reached the point of making companies reassess their brand and promotion strategies (Tavares \& Irving, 2009).

And it is in this Control Society (Deleuze, 1992) that the logic of consumption marked by social, economic, cultural and environmental movements, transmits multiple, hybrid and contradictory messages (Tavares et al., 2016). In this perspective, the practice of consumption brings an ambiguity of intent, not only when branded modeling translates into fashionable trends, but also into consumers concerned with consuming ethically and sustainably.

Within this ambivalent context, "green consumption" increasingly occupies space in the context of world consumption, developing through new market niches focused on the consumption of "green products" (Tavares \& Irving, 2009, 2013). In this context, the individual tries to reconstruct himself in order to reconfigure and readjust his forms of "being", "thinking", "acting" and "consuming", which refers to the concept of "escape line" defended by Deleuze \& Guattari (1995) as a way of reinventing oneself to feel part of a dimension adopted by the market.

Based on this principle, the present work intends to investigate, discuss and analyze the potential of locavorism as a significant movement, of resistance and activism in the conjuncture of the control society, linking the concepts of capitalist culture, subjectivity production and "escape line". Thus, this research was based on authors such as Gilles Deleuze, Felix Guattari and others who talk with them.

In order to understand the studied context, it was proposed a documentary exploratory study and field research, based on the Content Analysis methodology. Being the qualitative research, developed in the State of Rio de Janeiro, more specifically in the cities of Teresópolis and Campos de Goytacazes, the explora- 
tory field of the research took place in two local fairs of these respective cities, which are adept to the locavorist movement. Semi-structured questionnaires were applied to the fair's producers and potential consumers to collect interpretative material. To interpret the research results, we used the theoretical framework built by authors such as Felix Guattari and Gilles Deleuze, against the background of the Control Society analysis and the precepts that are configured in this context. Considering this, here are some clues about how the locavore movement developed in contemporary times.

\section{Literature Revision}

\subsection{Locavorism: Origin, Concepts and Features}

The term Food miles was coined by Tim Lang (professor at the University of London Center for Food Policy) in the early 1990s, bringing the logic of food activism encouraged by the idea of eating local food. In this perspective, by assessing the environmental impact factor of food and including the influence on global warming, new eyes were cast for this moment. The term "locavorism" or "Local Consumption" emerged in the United States in 2007 and has since spread around the world.

The word "locavore" in English, elected by the American Oxford Dictionary as the word of the year, was coined by Jessica Prentice, USA (Rudy, 2012). Locavorism aroused the engagement of many people in search of quality food, giving preference to genera grown by local producers or at most 200 kilometers from the place of cultivation. In Brazil, the movement took place around 2010, causing the emergence of a more aware and informed consumer about their responsibility through the exploitation of natural resources. From this perspective, locavorism can be stamped in the history of consumption as a driver of the insertion of nature as a form of consumer attraction and belonging to a certain group (Deleuze, 1992).

In the ambit of the desire for belonging, there is the insertion of the eyes from the perspective of the Society of Control (Deleuze, 1992). Freedom of choice goes through the obligation to acquire a particular product, giving the act of consumption the power to regulate the relationships and life of individuals. Thus, the logic of the control society appears with a subliminal message of domination and freedom, characteristic of societal capitalism. In the food segment, the new logic of the Control Society involves the "green market" as a possibility for regulation and subtle influence on consumer choices. This market is approached by Tavares et al. (2017) as a metamorphosis of the strategies of contemporary capitalism through immaterial, connectionist and natural values directed to the incessant production of desires as consumer identities and marking models produced from the exaltation of subjectivity (Tavares \& Irving, 2013).

According to Connolly \& Prothero (2008), locavorism brings, in essence, the "green consumption" promoted by the practice of which individuals feel responsible for the risks related to their health and the environment. This responsibility 
refers to the "escape line" (Deleuze \& Guattari, 1995) where "locavores" feel obliged to act to mobilize and address local, national and global environmental issues, spreading the culture of preservation and sustainability. Deleuze \& Guattari (1995) resort to the concept of "vanishing line", shaping a new power of reconstitution of the subject, in an attempt to rediscover in it organizations that reconfigure a way of being and thinking.

According to Azevedo (2015), the concern with local consumption permeates discussions about the ethics and lifestyle of producers, social roots, social relations and trust. Corroborating this idea, Halweil cited by Azevedo (2015) presents other benefits of the lavorist movement, such as fuel economy, fewer impacts on traffic, reduced food risks and less pollutant gas emissions. From this point of view, the locavorist movement can be elucidated as a form of "resistance", a model of "food activism" adopted by individuals who seem to metabolize the idea of "green consumption" as a project to contribute to nature improvements linked to care for your own health.

In contrast, Rudy (2012) states that locavorism goes beyond the question of how far food travels to its destination, including concern about where, how and by whom the food is produced and the ways in which these foods are marketed. Besides being a healthier practice for consumers and less harmful to the environment, it also stimulates the local economy.

Broadening the assessment of these clues from the market point of view, Tavares et al. (2015) mention that it is possible to speculate a metamorphosis about new demands, aiming to leverage the local economy based on "green consumption" and its benefits. The "green appeal" explored by the media may be contributing to the formation of individuals whose "identity is plural, changeable, fragmentary and flâneur” (Tavares et al., 2013: p. 1).

The main features surrounding the appreciation of locavorism in contemporary society may go beyond its importance to nature. The value that this nomenclature represents for the current market needs studies that also involve its consumers. With this identity and fluid approach, the idea of belonging and lifestyle is coordinated by the logic of the mutability of subjectivities (Deleuze \& Guattari, 2004) stimulated by the brand modeling, which have in their essence fluidity and plurality.

In this context, a kind of social domain emerges to which "everyone controls everyone" based on consumption and identity that are displayed and praised by groups that share the same ideals. Deleuze (1992) names the Control Society in a similar way to the social domain mentioned. Based on this, the question arises: Is the logic of the Society of Control the background for the formation of new subjectivities and new "ways of being"? The next topic aims to elucidate the Control Society in order to support the development of this research and its results.

\subsection{Control Society}

In contemporary new factors are perceived that have significantly changed the 
modus operandi that governs the consumption machine under the aegis of capital. Silva \& Tavares (2016) note that technological development, the compulsion for high performance in production, consumption desires transformed into needs, the creation of brand-oriented consumption models, among other aspects, made up a new marketing diagram governed by media campaigns.

In this new logic, the ephemerality and volatility of processes emerge as flagships of the strategic processes of dissemination of new behaviors and ideas. Consumption - by products or a kind of commodity nature-reveals itself as a driver of needs transformed into desires (Ferreira \& Tavares, 2017), in which the exchange process is now fed in favor of ephemerality and happiness, temporary linked to the act of consuming. In this new order of the Control Society (Deleuze, 1990), marked by the absence of defined limits and constant modulation, consumption becomes the driver that leverages the endless needs for satisfaction. Therefore, consumption (Deleuze, 1992) is considered as a control device, regulated by the market, where individuals who are part of this consumer society control each other, in the perception of belonging to an ideal.

In order to understand how these new processes in the control society may or may not influence the movement of locavorism, it is necessary to unveil the concepts that permeate the consumer society through different perspectives, in order to introduce the necessary bases to locate object of reflection of this research.

Guattari (1990) understands the consumer society as a society solidified by Integrated World Capitalism, showing a significant inclination to the subjective aspects that regulate social and consumer relations, affected by the logic of deterritorialization. Thus, the production of subjectivity (Guattari, 1990) under the order of the new capitalist society shows is decentralized, is embarking on several dimensions (social, political, environmental, economic, etc.) and producing behaviors that continually reinvent, In Deleuze's (1992) conception, the individual is constructed in his contact with the outside, changing by the constant possibility of reinventing himself and by the mutant subjectivity that the multiple dimensions present him.

Featherstone (1995) focuses on the investigation of identities as fragmented, hybrid and mobile. The displacement or "decentralization" of identity addresses profound changes in contemporary times, where individuals are crossed by transformations in the field of identity that occur through conflicts and cultural, symbolic and social fragmentation. This movement gives rise to fragmentation or "pluralization" of identities.

Given this, it can be inferred if there is, in this process, a transformation of locavore networks into brand modeling (Ferreira \& Tavares, 2017) that are soon consumed by the brilliance of a new buying opportunity, always more seductive than the previous one? Or was it really a form of resistance and activism in the logic of the controlling society? 


\section{Activism and Brand Modeling on the Organic Food Consumer Dish}

The diversity of food trends has emerged as a way to appease the busy life of large cities where food is considered precarious due to the lack of purity provided by pesticides and even the logistics to which they are exposed to the consumer's table. França et al. (2012) argue that nowadays people living in large centers have a tendency to revise their own food that presents a history from the urbanization/industrialization binomial, trying to make a counterpart with the slow food movement, which combines pleasure and regionality in the eating habit.

With this, people began common and enjoyable habits such as growing mini seasoning gardens in apartments that are part of the decoration and even the development of urban gardens through the cultivation of terraced vegetables or garages of buildings for the consumption of residents. This behavior can be identified as a form of "escape line" for individuals who need to live in the "jungle of stones" and cling to "green products" to ponder the insatiable consumerism that involves products of any origin.

Consumption is based on desire and no longer on the object and is praised by the consumer society that tends to enjoy the fads (Deleuze \& Guattari, 2004). Food fad can be a strong ally of the market, as it has a great ability to change the market share of this segment very quickly.

In a reportage, Rossi (2010) addresses nutritionist Osvaldinete Lopes de Oliveira mentioned "Just something to appear in the media and the other day the store is full". The nutritionist's comment refers to the "desiring machines" defended by Deleuze \& Guattari (2004) linked to the "subjectivity kits" mentioned by Tavares et al. (2013). The "green consumers" tend to develop consumption profiles stimulated by the media motivation added to the sustainability theme.

Locavores also advocate the practice of sustainability by reducing the emissions of toxic gases that occur during transport to the destination. In Mattoso (2016), experts argue that this is an illusory practice, since transportation influences, on average, less than $11 \%$ of the global carbon cost of a food item. In this case, the goal is much greater by obtaining the freshest and healthiest food closest to the place of planting and harvesting. The defense of nature appears as a positive point in the multiplicity of dimensions that are linked to "green products". This suggests that the control society acts as a backdrop for this type of consumer who tends to offer a high value to the produced nature.

According to Deleuze \& Guattari (1995), the value of nature through the market can be transformed into the price of goods through the way it can praise them through consumers. Therefore, locavorism may serve as an example for the authors' discourse, since the movement gained power through other foods. At the same time that the consumption of the individual can satisfy his desire for belonging, it can also provide the sale of nature because it has turned it into a commodity (Guattari \& Rolnik, 2000). 
The media agents work not only with brands, but also with the development of consumption profiles that, in the case of locavorism, will defend sustainability and healthy eating. As a worldwide trend, locavorism has been deterritorialized from its origin, which was in the USA, and has conquered several countries and chefs (METRÓPOLE REVISTA, 2019). For Pelbart (2003), deterritorialization may be the result of the deconstruction of the individual that makes room for the existence of "rhizomatic capitalism" that is immaterial, fluid and global. Thus, the next chapter brings the methodology adopted by this research to evaluate in locavores fairs the application of the concepts raised through the developed theoretical foundation. The objective is to unveil the extent to which this movement, in contemporary times, reflects a form of activism.

\section{Methodology}

To understand the process of consumption from locavorismo movement, the research followed the theoretical tracks traveled by Gilles Deleuze, Félix Guattari, and through the control of society clippings. From the construction of this theoretical framework, the methodology used to analyze the concepts in the practical case is exploratory research delivered through a qualitative study. Semi-structured questionnaires were applied in order to understand the context studied from exploratory study and field research. The interpretation of the questionnaires was developed from precepts inspired by the methodology of Content Analysis (Bardin, 1977). Being the qualitative research, developed in the State of Rio de Janeiro, more specifically in the cities of Teresópolis and Campos de Goytacazes, the exploratory field of the research took place in two local fairs that are adept to the locavore movement. The respondent social actors of this research were consumers to which 30 participants were at Feirinha da Roça, in Campos dos Goytacazes (Rio de Janeiro), and 30 were at the Family Agroecological Fair, in Teresópolis (Rio de Janeiro). Prior to applying the questionnaires, participants answered a filter question that limited collaboration to individuals who were buying the food and also consuming it. This restriction aims to obtain answers that contribute to the robustness of the results. After data collection, a global reading was performed so that the process of familiarity with the material would occur, and later the use of Content Analysis (Bardin, 1977) based on categorizations was started.

Regarding the application of Content Analysis according to Bardin's (1977) precepts, the author states that the intention is the inference of knowledge related to the conditions of production (or, eventually, reception), which uses indicators (quantitative or not) "[...] the analyst takes advantage of the treatment of the messages he manipulates, to infer (logically deduce) knowledge about the message sender or its environment, for example" (Bardin, 1977: p. 39).

Therefore, the interpretation must be clearly related to the existing corpus, so that it can be validated from the constructed theoretical foundation. The case study should therefore be systematized with the initial objectives, seeking the 
construction of scientific knowledge about the researched object, as can be observed below.

\section{Case Study: A Look at the Locavore Consumption in Rio de Janeiro}

One of the locavorism networks used as a case study was the "Feirinha da Roça", which occurs in Campos dos Goytacazes, in the interior of Rio de Janeiro State, 26 years ago. This fair is considered a leasehold network because its source of production is between the neighborhoods of Poço Gordo, Mussurepe, Saturnino Braga and São Sebastião, all at an average of 40 kilometers from the place of sale (campos.rj.gov.br, 2018). The second network of locavorism surveyed was the "Family Agroecological Fair", supervised by ATT-Teresópolis Agroecological Association-in the State of Rio de Janeiro. The fair has been operating in the region for 6 months and its products belong to the locavore network because they come from rural neighborhoods such as Santa Rita, Cruzeiro, Andradas, Bonsucesso and Vargem Grande, with a maximum distance of 28 kilometers between its production and points of sale.

\subsection{Initial Categories}

The initial categories are formed by the first impressions about the reality of consumption studied. All are the result of transcribed interviews that totaled 15 categories (Table 1).

Table 1. Initial categories.

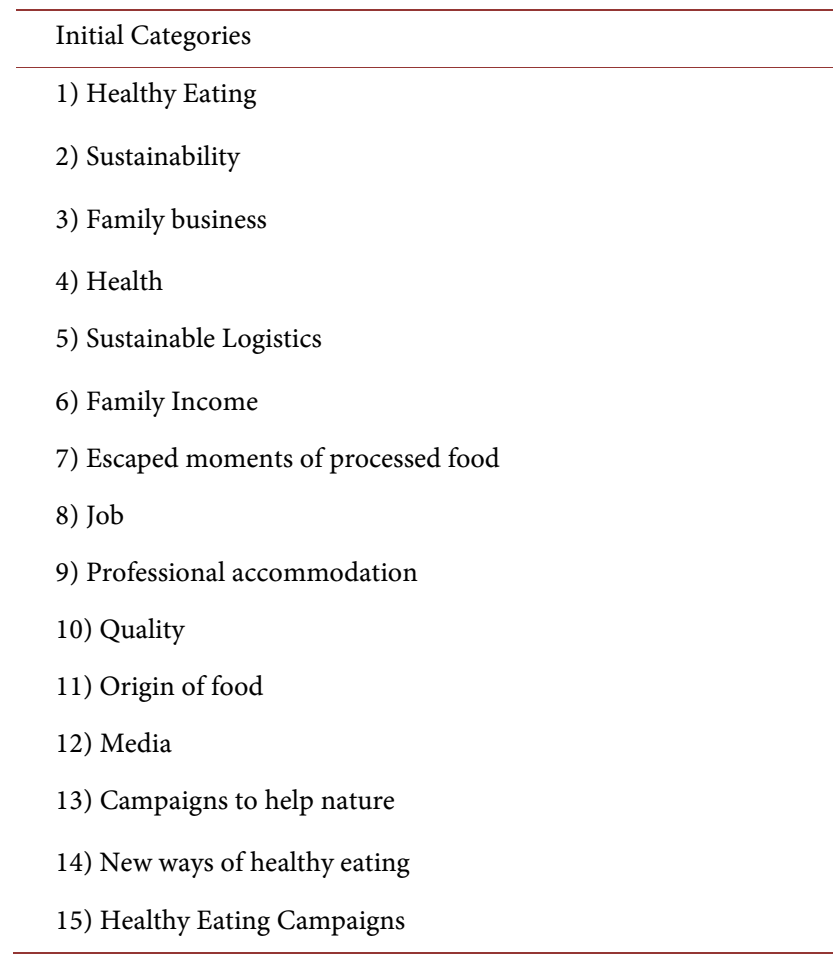

Source: Prepared by the authors from data collected in field research (2018). 
It can be observed in the initial categories that the approach of attributes inherent to individual issues such as "health" and collective issues such as "sustainable logistics" support the need for studies on locavorism to emerge. In this research, the subjectivity that enhances the behavior of organic food consumers is evaluated from the perspective of Gilles Deleuze and Félix Guattari in order to identify the force that the controlling society exerts on the transformation of "needs" into "desires" of these individuals.

In order to refine the initial categories through data analysis, intermediate categories based on a progressive grouping were developed. The intermediary categories will be presented in the following topic.

\subsection{Intermediate Categories}

The agglutination of the 4 initial categories culminated in the first intermediate category, called "proud entrepreneurship", as shown in Table 2.

Table 3 shows the second Intermediary category, "conscious consumer", which results from the agglutination of 6 initial categories.

Table 4 shows the second Intermediary category, "information-influenced consumption", which results from the agglutination of 5 initial categories. The intermediate categories "conscious consumer" and "information-influenced consumption" result in the contrast of the two final categories "green consciousness

Table 2. Intermediary category-proud entrepreneurship.

\begin{tabular}{crc}
\hline Initial Category & Guiding Concept & $\begin{array}{c}\text { Intermediary } \\
\text { Category }\end{array}$ \\
\hline Family business & $\begin{array}{r}\text { Indicates the participation of family members in the business } \\
\text { and all aware of the importance of locavorism } \\
\text { Family income }\end{array}$ & The fair is the largest source of family income \\
Job & The trade profession is assumed by the interview participants & proud \\
Professional & Highlights the lack of desire to expand the business & \\
\hline
\end{tabular}

Source: Prepared by the authors from data collected in field research (2018).

Table 3. Intermediary category-conscious consumer.

\begin{tabular}{ccc}
\hline $\begin{array}{c}\text { Initial Category } \\
\text { Healthy Eating } \\
\text { Health }\end{array}$ & Knowledge of the foods that are better for consumption & $\begin{array}{c}\text { Intermediary } \\
\text { Category }\end{array}$ \\
\hline $\begin{array}{c}\text { New ways of healthy eating } \\
\text { processed food }\end{array}$ & Evidence of recognition of your internal needs & Conscious \\
Origin of food & Reference to transferring lack of choice to selected food & consumer \\
Quality & Knowledge of processes precede consumption & \\
\hline
\end{tabular}

Source: Prepared by the authors from data collected in field research (2018). 
with little or no external influence" and "subjectivity kits". These are two possibilities that result from an escape line where individuals feel responsible for both the aggressions suffered by nature and those suffered by their own organism. By looking at this angle consumers can develop activist profiles or just influenced by brand modeling.

\subsection{Final Categories}

The final constitutions are developed from two final categories called "green consciousness with little or no external influence" and "subjectivity kits", as shown in Table 5, as they are the synthesis of the progression of the previous categories.

Consumers' wishes are considered insatiable and can be driven and "manipulated" through "brand modeling" that makes them feel that they belong to a desired style. In the research results, one can identify this in the initial category "moments of escape of the processed food". When the consumer recognizes that they are "moments of escape", he indirectly states that at other times he is a consumer of other foods that go through the industrialization process and, in many cases, are more harmful than vegetables that were not produced by locavorism networks. This schizophrenic behavior satisfies the "be", "being", "look" and "belonging" that satisfy the "control society" (Deleuze \& Guattari, 1995).

The schizophrenic behavior inherent in the "control society" (Deleuze, 1992) is also present in the results of the marketers locavores, as it appears in the intermediate category "entrepreneurship with pride". In this case, the marketer presents initial categories that refer to his professional need and later develop the

Table 4. Intermediary category-information influenced consumption.

\begin{tabular}{|c|c|c|}
\hline Initial Category & Guiding Concept & $\begin{array}{c}\text { Intermediary } \\
\text { Category }\end{array}$ \\
\hline Sustainability & Indicates knowledge of the term & \\
\hline Sustainable Logistics & Indicates the association of consumption with sustainability & Consumption \\
\hline Media & Reference Media Presence in Consumer Decisions & Influenced by \\
\hline Campaigns to help nature & Illustrates interest in participating in these campaigns & Information \\
\hline Healthy Eating Campaigns & Denote searching for information in this category & \\
\hline
\end{tabular}

Source: Prepared by the authors from data collected in field research (2018).

Table 5. Final categories.

\begin{tabular}{ccc}
\hline Intermediary Categories & Guiding Concept & Final Categories \\
\hline Entrepreneurship proud & Conscious work & $\begin{array}{c}\text { Green awareness with little or } \\
\text { no external influence }\end{array}$ \\
$\begin{array}{c}\text { Conscious Consumption } \\
\text { Consumption influenced by } \\
\text { information }\end{array}$ & $\begin{array}{c}\text { Activism } \\
\text { and desire for belonging }\end{array}$ & Subjectivity Kits \\
\hline
\end{tabular}

Source: Prepared by the authors from data collected in field research (2018). 
pride of participating in a network of cultivation of organic foods that do not use pesticides. In this case, he is professionally inserted by the family in the business without being aware of the importance of food for the health of consumers. Through the influences of consumers and the media they become proud and defend their segment with a differentiated conscience.

\section{Conclusion}

By contrasting the two possibilities, either as activism or resistance, or as marked modeling, the possibility arises that locavorism becomes a tool of rhizomatic capitalism from the perspective of the control society. This movement results from a multiplicity of networks of mutual influences that indicate that consumer behavior of natural products is linked to healthy eating that provides health and longevity. But also, it is observed that this consumption practice may not be linked only to the motivations surrounding green consumption. Through this view, it is observed that the practice of locavore consumption can bring an ambiguity of intentions. This is not only when brand modeling (Ferreira \& Tavares, 2017) translates into market trends, but also when it reflects consumers concerned about acting ethically and sustainably, but indicating a subtle way of expressing characteristics of activism.

It could be interpreted through this study that the "locavore" already outlines the need to belong to a group that supports its behavior as "activist and nature defender". This consumer may be unconsciously driven to consumption through a discharge of information that motivates him to adopt new market ideas at the expense of his previous consumption behavior. This behavior differs from the idea of "escape line", pointed by Deleuze \& Guattari (1995), in which there is the conception of a new power of reconstitution of the subject, reconfiguring new ways of being and thinking. On the other hand, the capitalist culture associated with these new "ways of being" culminates in the modeling of social actors through media strategies that make the individual feel healthy by belonging to a group of consumers of a particular dietary tendency or a new diet that promises aesthetic results linked to health.

These conclusions can be supported by a critical and comparative analysis between the intermediate categories "conscious consumer" and "informationinfluenced consumption". In this logic, the locavore consumer demonstrates an ambiguity of intentions supported by activist attributes and behavior that is influenced externally. This discrepancy in conduct also refers to the final results.

The final category "green consciousness with little or no outside influence" contradicts the one that resulted in "subjectivity kits". This is because while one demonstrates restrictions on the various external interventions that may arise, the other presents a mixture of persuasive feelings that directly interfere with consumption decisions, that is, there are no solid results for the defense of ideals nor for the fads that surround the market.

In view of the theoretical framework built here linked to field research, it 
cannot be said that the locavore movement is now consolidating itself as a form of solid resistance, that is, activism or brand modeling. This is because the analytical axes that resulted from the research were permeated and crossed throughout the investigation process. The relationships between food activism and trademark modeling involving the study of locavorism unleash various possibilities that can be constantly influenced and altered. Concerns inherent to the control society demand constant evaluations and locavorism is still a recent practice and may go through several phases, which points to the need for close monitoring from both the market and consumer point of view.

\section{Conflicts of Interest}

The authors declare no conflicts of interest regarding the publication of this paper.

\section{References}

Azevedo, E. (2015). O Ativismo Alimentar na perspectiva do Locavorismo. Ambiente \& Sociedade, 18, 81-98. https://doi.org/10.1590/1809-4422ASOC740V1832015

Bardin, L. (1977). Análise de conteúdo. Lisboa: Edições 70.

Bauman, Z. (2001). Modernidade líquida. Rio de Janeiro: Zahar.

campos.rj.gov.br (2018). Feira da Roça: Oportunidade de renda para os agricultores locais. https://www.campos.rj.gov.br/exibirNoticia.php?id_noticia=48656

Connolly, J., \& Prothero, A. (2008). Green Consumption: Life-Politics, Risk and Contradictions. Journal of Consumer Culture, 8, 117-145. https://journals.sagepub.com/doi/pdf/10.1177/1469540507086422 https://doi.org/10.1177/1469540507086422

Deleuze, G. (1990). Pourparlers. Paris: Les Éditions de Minuit.

Deleuze, G. (1992). Conversaçôes. Rio de Janeiro: Ed. 34.

Deleuze, G., \& Guattari, F. (1995). Mil platôs: Capitalismo e esquizofrenia. Vol. 1. Rio de Janeiro: Ed. 34.

Deleuze, G., \& Guattari, F. (2004). O anti-Édipo: Capitalismo e Esquizofrenia. Rio de Janeiro: Imago.

Featherstone, M. (1995). Cultura de consumo e pós-modernismo. Studio Nobel.

Ferreira, G. G. T., \& Tavares, F. (2017). Natureza líquida: As modelagens marcárias e os modos de ser na publicidade verde. Rio de Janeiro: Appris Editora.

França, F. C. O. et al. (2012). Mudanças dos hábitos alimentares provocados pela industrialização e o impacto sobre a saúde do brasileiro. Anais do I Seminário Alimentação e Cultura na Bahia, 1, 1-7.

http://www2.uefs.br:8081/cer/wp-content/uploads/FRANCA_Fabiana.pdf

Guattari, F. (1990). As três ecologias. Campinas: Papirus.

Guattari, F., \& Rolnik, S. (2000). Micropolítica: Cartografias do desejo. Rio de Janeiro: Vozes.

Mattoso, G. (2016). Locavorismo-O que os nossos vizinhos andam plantando. https://medium.com/clube-organico/locavorismo-o-que-os-nossos-vizinhos-andam-pl antando-c76af2612b16

METRÓPOLE REVISTA (2019). Conheça a prática do locavorismo ou consumo local. 
http://metropolerevista.com.br/metropole/conheca-a-pratica-do-locavorismo-ou-cons umo-local/27180

Pelbart, P. P. (2003). Vida capital: Ensaios de biopolítica. Iluminuras.

Prado, L. S. (2012). Em busca da identidade perdida. Revista Panorama, Goiânia, 2, 81-87.

Rossi, M. (2010). Cuidado com o Modismo Alimentar.

https://www.correiodoestado.com.br/noticias/cuidado-com-o-modismo\%20alimentar/ $\underline{1023 /}$

Rudy, K. (2012). Locavores, Feminism, and the Question of Meat. The Journal of American Culture, 35, 26-36.

https://onlinelibrary.wiley.com/doi/abs/10.1111/j.1542-734X.2011.00795.x

Silva, A., \& Tavares, M. (2016). Exemplos e práticas na produção dos "kits de subjetividade verde" como narrativas de modelagens marcárias no consumo da natureza. Revista Espaço Acadêmico, 16, 23-34.

http://www.periodicos.uem.br/ojs/index.php/EspacoAcademico/article/view/34410/17957

Tavares, F. A., Torres, G., Pontes, F., \& Topke, D. R. (2015). Women Go Shopping. Discussing the Female Intergenerational Behaviour and the "Green Consumption". Open Journal of Social Sciences, 3, 172-181.

https://file.scirp.org/pdf/JSS_2015091510504525.pdf

https://doi.org/10.4236/jss.2015.39024

Tavares, F. et al. (2017). The "Green Consumption" and the Rhizomatic Capital Strategy: Ads and Reports in the Brazilian Media. Advances in Applied Sociology, 7, 35-63.

https://www.scirp.org/pdf/AASoci_2017021315532574.pdf

https://doi.org/10.4236/aasoci.2017.72003

Tavares, F., \& Irving, M. (2009). Natureza S/A: O consumo verde na era do Ecopoder. Rio de Janeiro: Ed. Rima.

Tavares, F., Topke, D. R., Pontes, F., \& Ferreira, G. G. T. (2016). As mulheres vão às compras: um estudo teórico-empírico do comportamento feminino intergeracional e do "consumo verde" no Rio de Janeiro. RAU/UEG-Revista de Administração da $U E G, 7$.

https://www.revista.ueg.br/index.php/revista_administracao/article/view/3880/3249

Tavares, F., \& Ferreira, G. G. T. (2012). Marketing verde: Um olhar sobre as tensões entre greenwashing e ecopropaganda na construção do apelo ecológico na comunicação publicitária. Revista Espaço Acadêmico, 12, 23-31.

http://www.periodicos.uem.br/ojs/index.php/EspacoAcademico/article/view/18725/9948

Tavares, F., \& Irving, M. (2013). Sustentabilidade líquida: Ressignificando as Relações entre Natureza, Capital e Consumo em tempos de fluidez. Revista Espaço Acadêmico-UEM, 13, 1-11.

http://www.periodicos.uem.br/ojs/index.php/EspacoAcademico/article/view/22190/12115

Tavares, F., Irving, M. A., \& Vargas, R. O. (2013). “Sustentabilidade líquida”: Ressignificando as Relações entre Natureza, Capital e Consumo em tempos de fluidez. Revista Espaço Acadêmico, 13, 1-11. 